\title{
CAtherine BAtes. On Not Defending Poetry: Defence and Indefensibility in Sidney's
}

Defence of Poesy. Pp. xviii + 299. Oxford: Oxford University Press, 2017. Cloth, £65.

The earliest readers of Philip Sidney's Defence of Poesy knew that it must be handled with care. The rigorous logical analysis of the text undertaken for Sidney's benefit by William Temple in 1585 pinpoints numerous faults in its reasoning; some propositions Temple allows, others he patiently and politely rebuts. In like vein, much modern writing about the Defence has deemed it divided or incoherent, a not quite achieved synthesis. Catherine Bates's new monograph is thus not original in seeing the Defence as 'a text terminally in conflict with itself' (p. 10). Nevertheless, this is an avowedly revisionist study, passionately and even angrily argued, and designed to shake critics from their complacent if tacit complicity in the 'idealist' aesthetics of ethically inflected mimesis which is the 'official' centrepiece of Sidney's poetics. For Bates, Sidney has become 'the Establishment's poster boy for a legitimate and defensible professional literary criticism' (p. 65); but the Defence's ostensible argument is shot through with ideology, and its insistence on the imitative replication of worthy Cyruses presents 'a nightmare scenario of identical robots programmed to produce more of the same'. 'Critics invested in such a model for their discipline', Bates trenchantly asserts, 'seem neither to be aware of nor to care about the offensive nature of the tactics the speaker uses to defend it' (p. 120). Bates argues that the Defence persistently if unwittingly exposes the darker foundations on which it is built: she reads Sidney's often 'tortuous' text 'symptomatically', seeing each of its notorious slips of logic and syntactic evasions as 'a classic sign of resistance, conscious or otherwise' to its own avowed intent (p. 52); and she distinguishes both between the 'speaker' of the Defence and the historical Sidney, and, following Freud, Marx, and Jameson, between the work's 'manifest and latent content' ( $p$. 10). Such formulations indicate the book's methodological temper and affinities. 
The sheer density of the book's quotation, analysis, and theoretical engagement makes a calculated mockery of lucid summary. The first of its three parts explores Sidney's apparent assertion (against voices to the contrary) that poetry is profitable, using recent economic criticism by Marc Shell and Jean-Joseph Goux to uncover the deep and insidious structures of 'money thought' that underpin the promised 'golden' world of Sidneian poetics. The second section considers the imperfectly concealed contradictions in Sidney's defence of poetry from the charge of lying; and the third deals with the Defence's rebuttal and redirection of the accusation that poetry abuses its readers by inciting wantonness, undermining societal conventions, and, ultimately, calling the idealist metaphysics of presence into doubt. These sections correspond to the principal attacks mounted against poetry by Stephen Gosson, whose dedication to Sidney of his Schoole of Abuse in 1579 is commonly held to have been the Defence's casus belli. This structuring principle is quite deliberately honoured more in the breach than the observance: ideas are picked up, put down, and returned to throughout the book, so that no part or chapter is wholly discrete. This is in keeping with the deconstructive mode in which the book is written, and serves to insure against the falsification of the Defence's complexity that would come from putting its overlapping concerns too neatly into boxes (as tidy-minded early readers like William Temple might have wanted to do). Bates reads the Defence as discontinuous, multivocal, unresolved, and always ironically other than itself; and she mimics this in her own book, most of whose pages bear long discursive footnotes which litigate her disagreements with an array of other critics. These paratextual animadversions are often important to Bates's argument but necessarily interrupt our reading; the effect is surely deliberate, part of a strenuous playfulness which is among the book's most notable features. Bates's own text often seems to tread that paradoxical 'path' she identifies in Sidney's: 'it does not have a clear destination, except, perhaps, to lose, confuse, and disorient those who are (or who want 
to be) on the straight one' (p. 172). At one point she suggests that the 'superfluous' speech of the horseman John Pietro Pugliano, with which the Defence begins, and which has 'the status and logic of the supplement', 'serves as Sidney's model' for the impressive but gratuitous and unproductive discourse he unofficially and illicitly advocates (pp. 159, 170). Bates makes this point in a compelling chapter whose own copious fluency both enacts and ironizes its assertion that 'Pugliano's fertile wit is infinitely generative $[\ldots]$ but it is an airy productivity' whose utterances 'belong [...] to the order of luxury goods: fashioned, beautiful, intensely desired, yet strictly useless, dispensable, inessential, supplementary, and quite possibly counterfeit or fake' (p. 162). Such sentences are surely designed to discomfort professional literary critics and to satirize the economies they inhabit.

This is, therefore, a demanding, provocative, stimulating, detailed, and, for all these reasons, most welcome book. Bates would not want a reviewer to deem it 'valuable', since the economics, truth-claims, and metaphysics of 'value' are its most constant targets. Some may find it methodologically objectionable or untimely: it is, for example, deliberately antipathetic to historicist modes of reading, and is hard to reconcile with the carefully contextualized recent work on Sidney's earnest links with European learning and cosmopolitan Protestantism. The historical Sidney need never trouble Bates's analysis, however, because she undertakes to deconstruct any sense that Sidney was a stable and unified self who could guarantee the Defence's argumentative coherence. As Bates briefly acknowledges (p. x), her confidently radical presentism risks becoming conceitedly moralistic, an ahistorical liberal humanism masquerading as critique: she calls out the humanist poetics of the Renaissance for its ideological wrongs while speculating that, deep down, Sidney shared the non-instrumental aesthetics of the modern critic. Bates sees no remedy to this danger save to acknowledge it, which cannot wholly dispel suspicion of special pleading. Since 'Sidney's alternative vision of poetry' is not attributed to his 
conscious intent but found, as if by 'a kind of infra-red night-vision', 'by extrapolating it from and inferring it as everything that the official, positivized model is not' (p. 131), Bates's arguments are paradoxically both unprovable and irrefutable.

On a more particular methodological level, Bates's habits of quotation from the Defence are open to criticism. Certain passages central to her case are returned to again and again, while others receive surprisingly scarce treatment: relatively little is made of Sidney's morally serious distinction between 'erected wit' and 'infected will', and no mention at all is made of 'the ethic and politic consideration' so central to the text's conceptual architecture, nor of Sidney's own description of the Defence as an 'ink-wasting toy', nor of the evidently sarcastic closing passage which 'conjures' and exhorts the reader to 'believe' its arguments. These omissions are notable in an analysis which seems on first sight exhaustive, so copious are its quotations. Just occasionally, short phrases are wrested from their contexts and put to uses not quite justified by the text. William Temple would have cavilled at this; and while Temple's dutiful and scrupulous sobriety is temperamentally alien to Bates's approach, his insistence that we take Sidney's 'official' arguments seriously even as we confront the Defence's antinomies is not wholly superseded by her arguments, however invigorating to Sidney studies they should prove to be.

Michael Hetherington, St John's College, Oxford 